Article

\title{
Could Supercritical Extracts from the Aerial Parts of Helianthus salicifolius A. Dietr. and Helianthus tuberosus L. Be Regarded as Potential Raw Materials for Biocidal Purposes?
}

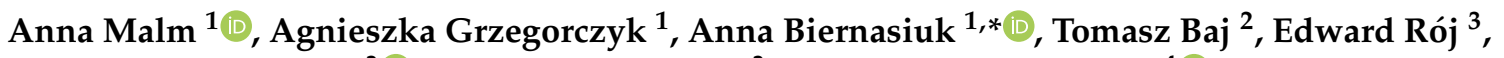 \\ Katarzyna Tyśkiewicz ${ }^{3}{ }^{\oplus}$, Agnieszka Dębczak ${ }^{3}$, Mariusz Jerzy Stolarski ${ }^{4}{ }^{(0}$, Michał Krzyżaniak ${ }^{4}(\mathbb{D}$ \\ and Ewelina Olba-Zięty ${ }^{4}$ (i)
}

1 Department of Pharmaceutical Microbiology, Faculty of Pharmacy, Medical University of Lublin, Chodźki 1, 20-093 Lublin, Poland; anna.malm@umlub.pl (A.M.); agnieszka.grzegorczyk@umlub.pl (A.G.)

2 Department of Pharmacognosy, Faculty of Pharmacy, Medical University of Lublin, Chodźki 1, 20-093 Lublin, Poland; tomasz.baj@umlub.pl

3 Supercritical Extraction Department, Łukasiewicz Research Network-New Chemical Syntheses Institute, Al. Tysiąclecia Państwa Polskiego 13A, 24-110 Puławy, Poland; edward.roj@ins.lukasiewicz.gov.pl (E.R.); katarzyna.tyskiewicz@ins.lukasiewicz.gov.pl (K.T.); agnieszka.debczak@ins.lukasiewicz.gov.pl (A.D.)

4 Department of Plant Breeding and Seed Production, Faculty of Environmental Management and Agriculture, Centre for Bioeconomy and Renewable Energies, University of Warmia and Mazury in Olsztyn, Plac Łódzki 3 , 10-724 Olsztyn, Poland; mariusz.stolarski@uwm.edu.pl (M.J.S.); michal.krzyzaniak@uwm.edu.pl (M.K.); e.olba-ziety@uwm.edu.pl (E.O.-Z.)

* Correspondence: anna.biernasiuk@umlub.pl

\section{check for}

updates

Citation: Malm, A.; Grzegorczyk, A.; Biernasiuk, A.; Baj, T.; Rój, E.; Tyśkiewicz, K.; Dębczak, A.; Stolarski, M.J.; Krzyżaniak, M.; Olba-Zięty, E. Could Supercritical Extracts from the Aerial Parts of Helianthus salicifolius A Dietr. and Helianthus tuberosus L. Be Regarded as Potential Raw Materials for Biocidal Purposes? Agriculture 2021, 11, 10. https://dx.doi.org/ 10.3390/agriculture11010010

Received: 31 October 2020 Accepted: 23 December 2020

Published: 26 December 2020

Publisher's Note: MDPI stays neutral with regard to jurisdictional claims in published maps and institutional affiliations.

Copyright: () 2020 by the authors. Licensee MDPI, Basel, Switzerland. This article is an open access article distributed under the terms and conditions of the Creative Commons Attribution (CC BY) license (https: / / creativecommons.org/ licenses/by/4.0/).
Abstract: Extracts from the June collection of aerial parts of Helianthus salicifolius A. Dietr and Helianthus tuberosus L. were obtained using carbon dioxide supercritical fluid extraction with water as co-solvent. The antimicrobial effect in vitro of these extracts was then determined against reference species of bacteria, as well as against fungi (represented by Candida spp.). Both extracts were found to possess antimicrobial activity, with MIC $=0.62-5 \mathrm{mg} \mathrm{mL}^{-1}$ for bacteria and MIC $=5-10 \mathrm{mg} \mathrm{mL}^{-1}$ for yeasts, and both extracts demonstrated suitable bactericidal and fungicidal effect. The highest activity was observed against $S$. aureus ATCC 29213 (MIC $=0.62 \mathrm{mg} \mathrm{mL}^{-1}$ for $H$. salicifolius extract; MIC $=2.5 \mathrm{mg} \mathrm{mL}^{-1}$ for $H$. tuberosus extract) as confirmed by time-kill assay. Higher antioxidant activity was found for $H$. tuberosus extract $\left(\mathrm{EC}_{50}=0.332 \mathrm{mg} \mathrm{mL}^{-1}\right)$ as compared to that of $H$. salicifolius $\left(E_{50}=0.609 \mathrm{mg} \mathrm{mL}^{-1}\right)$. The total polyphenol content $(\mathrm{TPC})$ expressed as gallic acid equivalents (GAE) was $13.75 \pm 0.50 \mathrm{mg} \mathrm{GAE} \mathrm{g}^{-1}$ of $H$. salicifolius extract and $33.06 \pm 0.80 \mathrm{mg} \mathrm{GAE} \mathrm{g}^{-1}$ of $H$. tuberosus extract. There was a relationship between the antioxidant potential of both extracts and TPC, but not between antistaphylococcal activity and TPC. The ATIR-FTIR spectra of both extracts showed similar main vibrations of the functional groups typical for phytoconstituents possessing bioactivity. The obtained data suggest potential application of these extracts as natural antioxidants and preparations with biocidal activity. Additionally, both extracts may be regarded as potential natural conservants in cosmetics, as well as natural preservatives in food.

Keywords: willow-leaf sunflower; Jerusalem artichoke; supercritical extraction; water as co-solvent; antimicrobial activity; biocidal effect

\section{Introduction}

Perennial herbaceous crops, including Helianthus tuberosus L. (also called Jerusalem artichoke or topinambur) and Helianthus salicifolius A. Dietr, (willow-leaf sunflower) belong to the group of plants of potentially high importance for energy use [1,2]. This is due to high biomass production and limited cultivation requirements. It should be added that these species are resistant to frost and possible infestation by diseases and pests. However, when harvesting the aerial parts biomass of these species, there may be periodic lodging 
problems, which may make harvesting difficult, but this occurs mainly at the end of the vegetation period [2]. While the biomass of these species can be a raw material for the production of biogas, liquid biofuels, and solid biofuels [3-6], it should be emphasized that the energetic use of biomass of these species maybe of the least value regarding their production purposes.

Recently, much attention has been paid to various plants as a source of alternative antimicrobial compounds and strategies. It is well-known that plants are valuable and rich sources of a wide range of secondary metabolites that possess multidirectional biological activity [7]. Studies suggest that $H$. tuberosus exerts antioxidant, anticancer, antidiabetic, and $\alpha$-glucosidase inhibitory activity and produces inulin. Indeed, studies have noted the antimicrobial activity of $H$. tuberosus, e.g., against several fungal phytopathogens such as Rhizoctonia solani, Gibberella zeae, Alternaria solani, Botrytis cinerea, Colletotrichum gloeosporioides, and Phytophthora capsici Leonian [8-10]. However, no data concerning antimicrobial (antifungal) properties of $H$. salicifolius are available. The possibility, therefore, exists that Jerusalem artichoke and willow-leaf sunflower can be used as functional food with many medical benefits [11,12]. Thus, new possibilities of using the biomass of these species should be searched for in order to obtain bioactive substances from them and ascertain their further application in the production of high-value bioproducts.

The aim of this study was to determine the antimicrobial properties of extracts obtained from the aerial parts of $H$. salicifolius and $H$. tuberosus using carbon dioxide supercritical fluid extraction with water as co-solvent. The biomass for the extraction purposes was collected at the end of June. The extracts were assayed for their activity together with the mode of action (bactericidal/fungicidal vs. bacteriostatic/fungistatic) against Gram-positive (Staphylococcus aureus) and Gram-negative (Escherichia coli) bacteria and against fungi (yeasts from Candida spp.)-these being the component of human skin, oral, and gut microbiota, which under predisposing conditions can be considered human pathogens [13-15]. The antimicrobial activity of these extracts was analyzed in a correlation with their total polyphenol content (TPC) and antioxidant properties. Attenuated total reflection-Fourier transform infrared (ATR-FTIR) spectra analyses of the extracts were also performed in order to obtain preliminary data on the presence of functional groups characteristic for bioactive phytoconstituents.

\section{Materials and Methods}

\subsection{Plant Material}

The green aerial parts biomass of $H$. salicifolius and H. tuberosus were collected on June 24, 2019, from the experimental plantation owned by the University of Warmia and Mazury in Olsztyn (Figure 1). This was biomass from the beginning of the growing season (April-June) obtained from nine-year-old stools. The plot size was $20 \mathrm{~m}^{2}$. The plants were harvested with a lawn trimmer and weighed on an electronic scales. During the harvest, biomass samples were obtained in order to determine its moisture content. On the basis of the yield of fresh biomass and its moisture content during harvest, the yield of dry biomass was calculated and expressed in $\mathrm{Mg} \mathrm{ha}^{-1}$. The number of replications was three. After harvesting, the biomass of $H$. salicifolius and $H$. tuberosus was transported to the drying plant. This biomass was then dried at $40{ }^{\circ} \mathrm{C}$ to a moisture level below $10 \%$. After drying, it was ground using a mill with $6 \mathrm{~mm}$ mesh sieves. Subsequently, the biomass was packed in bags and transported to the supercritical extraction plant. 


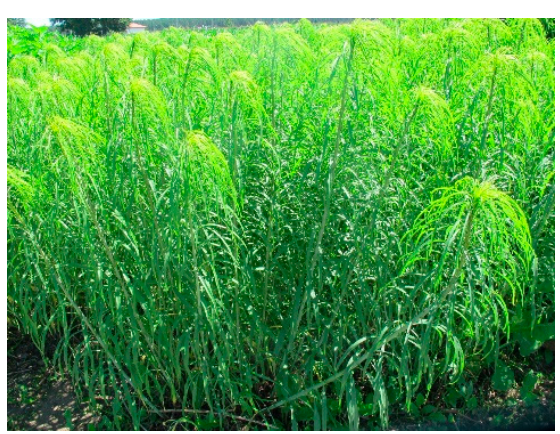

(a)

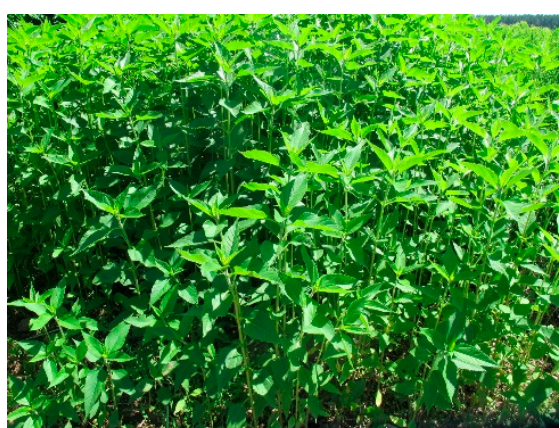

(b)

Figure 1. (a) H. salicifolius and (b) H. tuberosus plants during the harvest period June 24, 2019, (photo: M.J.S.).

\subsection{Extraction Method}

The ground material was extracted with supercritical carbon dioxide with the addition of water as co-solvent in the amount of $1 \mathrm{wt} \%$. The supercritical fluid extraction was performed on a pilot plant produced by Natex, Austria, with two extractors of $40 \mathrm{dm}^{3}$ each, working under the pressure of up to 1000 bar and temperature up to $90^{\circ} \mathrm{C}$. Each raw material ( $5 \mathrm{~kg}$ for $\mathrm{H}$. salicifolius and approx. $2 \mathrm{~kg}$ for $\mathrm{H}$. tuberosus) was extracted with co-solvent under parameters that were set as follows: temperature at $40{ }^{\circ} \mathrm{C}$ and pressure at 330 bar. The extract obtained was in the form of an aqueous mixture. The water was evaporated using a Buchi R-220SE vacuum evaporator. The extraction yield expressed in \% was determined for the dried extract in relation to the raw material as the ratio of the amount of dried extract to the mass of raw material. These supercritical extracts were named further as $\mathrm{CO}_{2}+\mathrm{H}_{2} \mathrm{O}$ extracts.

\subsection{Determination of Total Polyphenol Content (TPC)}

The total phenolic content in $\mathrm{CO}_{2}+\mathrm{H}_{2} \mathrm{O}$ extracts from $\mathrm{H}$. salicifolius and $\mathrm{H}$. tuberosus was determined spectrophotometrically by a modified method previously described by Clarke et al. [16] and Nickavar and Esbati [17]. A $20 \mu \mathrm{L}$ of extract dissolved in DMSO (conc. $10 \mathrm{mg} \mathrm{mL}^{-1}$ ) and $100 \mu \mathrm{L}$ of freshly prepared Folin-Ciocalteu reagent (diluted $1 / 10$ with redistilled water) were added to the wells of a 96 -well plate. After $5 \mathrm{~min}, 100 \mu \mathrm{L}$ of a $7.5 \%$ $\mathrm{Na}_{2} \mathrm{CO}_{3}$ solution was added. The plates with the mixtures were incubated for $60 \mathrm{~min}$. at room temperature; the absorbance was then measured using an $\mathrm{EPOCH}$ spectrophotometer (Biotek, USA, Software ver. 3.08.01) at a wavelength of $760 \mathrm{~nm}$. The same method was used to establish a calibration curve for the standard gallic acid in the concentration ranges $7.5-120.0 \mu \mathrm{g} \mathrm{mL}^{-1}\left(\mathrm{y}=0.054 \mathrm{x}+0.029, \mathrm{R}^{2}=0.996\right)$. The analysis was performed in triplicate using DMSO as the blank. The content of total phenolic content expressed in equivalents as mg GAE/g of extract was calculated according to the formula described elsewhere [18].

\subsection{Determination of Antibacterial and Antifungal Activity}

The assay of antibacterial and antifungal activity of $\mathrm{CO}_{2}+\mathrm{H}_{2} \mathrm{O}$ extracts from $\mathrm{H}$. salicifolius and $H$. tuberosus was performed by the broth microdilution method according to EUCAST (the European Committee on Antimicrobial Susceptibility Testing) recommendations [19]. The following reference strains were used in the study: Staphylococcus aureus ATCC 29213 (representative of Gram-positive bacteria), Escherichia coli ATCC 25922 (representative of Gram-negative bacteria), Candida albicans ATCC 10231, and Candida glabrata ATCC 90030 (representatives of yeast fungi). All the used microbial strains were first subcultured on Mueller-Hinton Agar (MHA for bacteria) or Mueller-Hinton Agar with $2 \%$ glucose (MHA $+2 \%$ glucose for fungi) and incubated at $35^{\circ} \mathrm{C}$ for $24 \mathrm{~h}$. Microbial colonies were collected and suspended in sterile physiological saline to obtain inoculum of $0.5 \mathrm{McFarland}$ standard, corresponding to $1.5 \times 10^{8} \mathrm{CFU}$ (colony forming units) $\mathrm{mL}^{-1}$ 
for bacteria and $5 \times 10^{6} \mathrm{CFU} \mathrm{mL}{ }^{-1}$ for fungi. The $\mathrm{CO}_{2}+\mathrm{H}_{2} \mathrm{O}$ extracts were dissolved in DMSO to obtain the final concentration $100 \mathrm{mg} \mathrm{mL}^{-1}$.

The two-fold dilutions of the extracts in Mueller-Hinton Broth (MHB for bacteria) or by Mueller-Hinton Broth with $2 \%$ glucose (MHB $+2 \%$ glucose for fungi) were prepared in 96-well polystyrene plates. The final concentrations of the extracts ranged from 40 to $0.155 \mathrm{mg} \mathrm{mL}^{-1}$. Next, $2 \mu \mathrm{L}$ of each bacterial or fungal inoculum was added to each well containing $200 \mu \mathrm{L}$ of the serial dilution of the extracts in the appropriate culture medium. After incubation at $35^{\circ} \mathrm{C}$ for $24 \mathrm{~h}$, the MIC (Minimum Inhibitory Concentration) was assessed spectrophotometrically as the lowest concentration of the extract showing complete bacterial or fungal growth inhibition. Appropriate DMSO, growth, and sterile controls were carried out. Vancomycin (range of 0.03-10 $\mu \mathrm{g} \mathrm{mL}^{-1}$ ), ciprofloxacin (range of $0.007-10 \mu \mathrm{g} \mathrm{mL}^{-1}$ ), and fluconazole (range of $0.03-10 \mu \mathrm{g} \mathrm{mL}^{-1}$ ) were included as the reference antimicrobial substances active against Gram-positive bacteria, Gram-negative bacteria, and yeasts. The MBC (minimum bactericidal concentration) or MFC (minimum fungicidal concentration) were determined by removing $20 \mu \mathrm{L}$ of the bacterial or fungal culture used for MIC determinations from each well and spotting this onto appropriate agar medium. The plates were incubated at $35^{\circ} \mathrm{C}$ for $24 \mathrm{~h}$. The lowest extracts concentrations with no visible bacterial or fungal growth were assessed as MBC or MFC, respectively. The experiments were performed in triplicate. Of the three MIC, MBC, and MFC values, the most common representative value, i.e., mode was presented.

\subsection{Determination of Antioxidant Activity}

The antioxidant activity of $\mathrm{CO}_{2}+\mathrm{H}_{2} \mathrm{O}$ extracts from $\mathrm{H}$. salicifolius and $\mathrm{H}$. tuberosus extracts was determined using the method described by Gai et al. [20] with modifications. Briefly, a starting solution was prepared by dissolving $10 \mathrm{mg}$ of extract in $1 \mathrm{~mL}$ of DMSO solution. A series of dilutions were then prepared in the same solvent at a concentration of $0.16-10 \mathrm{mg} \mathrm{mL}^{-1}$. Subsequently, $0.05 \mathrm{~mL}$ of each concentration was mixed with $0.15 \mathrm{~mL}$ of DPPH methanol solution $\left(0.078 \mathrm{mg} \mathrm{mL}^{-1}\right)$. The 96 -well plate with the mixtures was incubated in the dark for $30 \mathrm{~min}$ in room temperature. Absorbance was measured at $515 \mathrm{~nm}$ (Biotek, Epoch, Software Version 3.08.01). The extract concentration needed to capture 50\% of the initial DPPH $\left(\mathrm{EC}_{50}\right)$ was determined automatically using four parameter logistic regression (4LP) from the plate reader software Gen5. The experiments were performed in triplicate.

\subsection{Attenuated Total Reflection-Fourier Transform Infrared (ATR-FTIR) Spectra Analysis}

ATR-FTIR spectra of $\mathrm{CO}_{2}+\mathrm{H}_{2} \mathrm{O}$ extracts obtained from $\mathrm{H}$. salicifolius and $\mathrm{H}$. tuberosus were recorded on a Bruker Tensor 27 FTIR spectrometer (Bruker Optic GmbH, Aetlingen, Germany) equipped with single-bounce diamond ATR (Platinum ATR, Bruker Optic $\mathrm{GmbH}$, Aetlingen, Germany). The spectrometer was controlled with the software OPUS 6.5 (Bruker Optic). The scan number of the spectra was 16 recorded at $4 \mathrm{~cm}^{-1}$ resolution in the wavenumber range from 4000 to $400 \mathrm{~cm}^{-1}$. A small amount of each extract $(5 \mathrm{mg})$ was placed on the ATR surface that was cleaned using ethanol to eliminate any contamination by the previous sample. A new background was recorded between each replicate, and the scans were run in triplicates.

\section{Results}

The height of the nearly three-month-old plants of both species was $1.1 \mathrm{~m}$ (Table 1). $H$. salicifolius produced slightly thicker shoots, and therefore the yield of fresh biomass for this species was higher and amounted to $12.9 \mathrm{Mg} \mathrm{ha}^{-1}$. Moisture of $H$. salicifolius biomass was $79 \%$ and was almost two percentage points lower compared to that of $H$. tuberosus. Therefore, the dry matter yield of $H$. salicifolius harvested at the end of June was $2.7 \mathrm{Mg} \mathrm{ha}^{-1}$ and was higher by $0.5 \mathrm{Mg} \mathrm{ha}^{-1}$ compared to the yield of $H$. tuberosus. 
Table 1. Biometric features, moisture content, and yield of fresh and dry biomass of H. salicifolius and H. tuberosus.

\begin{tabular}{|c|c|c|c|c|c|}
\hline Species & Plant Height (m) * & $\begin{array}{l}\text { Shoot Diameter } \\
(\mathrm{mm}) *\end{array}$ & $\begin{array}{c}\text { Fresh Biomass } \\
\text { Yield }\left(\mathrm{Mg} \mathrm{ha}^{-1}\right)\end{array}$ & $\begin{array}{l}\text { Moisture Content } \\
(\%) * *\end{array}$ & $\begin{array}{c}\text { Dry Biomass } \\
\text { Yield }\left(\mathrm{Mg} \mathrm{ha}^{-1}\right) \text { ** }\end{array}$ \\
\hline H. salicifolius & $1.1 \pm 0.9$ & $7.0 \pm 1.0$ & $12.9 \pm 2.2$ & $79.1 \pm 0.4$ & $2.7 \pm 0.4$ \\
\hline H. tuberosus & $1.1 \pm 0.4$ & $5.9 \pm 0.6$ & $11.6 \pm 3.3$ & $81.0 \pm 1.1$ & $2.2 \pm 0.8$ \\
\hline
\end{tabular}

Mean values \pm standard deviation were presented; ${ }^{*} n=30 ;{ }^{* *} n=3$.

The results presented in Table 2 show that the extraction efficiency of $H$. salicifolius (4.97\%) was much higher than that of $H$. tuberosus. Due to the fact that the yield of $H$. salicifolius aerial parts biomass was also higher, the amount of extract that could be obtained from the cultivation of this species was approximately $134 \mathrm{~kg} \mathrm{ha}^{-1}$. On the other hand, the production potential of $H$. tuberosus extract was almost 20 times lower.

Table 2. Extraction efficiency and extract potential yield of $H$. salicifolius and H. tuberosus from dry biomass under supercritical conditions with the participation of water as a co-solvent $\left(\mathrm{CO}_{2}+\mathrm{H}_{2} \mathrm{O}\right.$ extracts).

\begin{tabular}{ccc}
\hline Plant Material & Extraction Efficiency (\%) & Extract Potential Yield (kg ha $\mathbf{~}^{\mathbf{1}}$ ) \\
\hline H. salicifolius & 4.97 & 134.19 \\
H. tuberosus & 0.31 & 6.82 \\
\hline
\end{tabular}

As revealed in Table 3, the $\mathrm{CO}_{2}+\mathrm{H}_{2} \mathrm{O}$ extracts obtained from $H$. salicifolius and $H$. tuberosus showed differential activity against bacteria (MIC $=0.62-5 \mathrm{mg} \mathrm{mL}^{-1}$ ) and yeasts (MIC $=5-10 \mathrm{mg} \mathrm{mL}^{-1}$ ). The highest activity of both extracts was observed against $S$. aureus ATCC 29213 with MIC $=0.62 \mathrm{mg} \mathrm{mL}^{-1}$ for H. salicifolius extract and MIC $=2.5 \mathrm{mg} \mathrm{mL}^{-1}$ for $H$. tuberosus extract. MIC for the reference antimicrobial substances were as the following: MIC of vancomycin for S. aureus ATCC 29213 was $1 \mu \mathrm{g} \mathrm{mL}^{-1}$, MIC of ciprofloxacin for $E$. coli, ATCC 25922 was $0.015 \mu \mathrm{g} \mathrm{mL}^{-1}$ and MIC of fluconazole for C. albicans, and ATCC was $1 \mu \mathrm{g} \mathrm{mL}^{-1}$. As presented in Table 3 , both extracts possessed bactericidal $(\mathrm{MBC} / \mathrm{MIC}=1-4)$ and fungicidal effect (MFC/MIC $=1-2$ ). It is generally accepted that antimicrobials are usually regarded as bactericidal or fungicidal if the MBC/MIC or MFC/MIC ratio is $\leq 4$ [21].

Table 3. Antimicrobial activity of supercritical extracts obtained from $H$. salicifolius and $H$. tuberosus with water as a co-solvent $\left(\mathrm{CO}_{2}+\mathrm{H}_{2} \mathrm{O}\right.$ extract).

\begin{tabular}{|c|c|c|c|c|c|c|}
\hline \multirow{3}{*}{$\begin{array}{c}\text { Microorganisms } \\
\text { Bacterial } \\
\text { Strains }\end{array}$} & \multicolumn{6}{|c|}{ Extracts } \\
\hline & \multicolumn{3}{|c|}{ H. salicifolius } & \multicolumn{3}{|c|}{ H. tuberosus } \\
\hline & $\begin{array}{c}\text { MIC } \\
{\left[\mathrm{mg} \mathrm{mL}^{-1}\right]}\end{array}$ & $\begin{array}{c}\mathrm{MBC} \\
{\left[\mathrm{mg} \mathrm{mL}^{-1}\right]}\end{array}$ & $\begin{array}{l}\mathrm{MBCl} \\
\mathrm{MIC}\end{array}$ & $\begin{array}{c}\mathrm{MIC} \\
{\left[\mathrm{mg} \mathrm{mL}^{-1}\right]}\end{array}$ & $\begin{array}{c}\mathrm{MBC} \\
{\left[\mathrm{mg} \mathrm{mL}^{-1}\right]}\end{array}$ & $\begin{array}{l}\text { MBC/ } \\
\text { MIC }\end{array}$ \\
\hline $\begin{array}{c}\text { Staphylococcus aureus } \\
\text { ATCC } 29213\end{array}$ & 0.62 & 2.5 & 4 & 2.5 & 5 & 2 \\
\hline $\begin{array}{l}\text { Escherichia coli } \\
\text { ATCC } 25922\end{array}$ & 5 & 10 & 2 & 5 & 5 & 1 \\
\hline $\begin{array}{c}\text { Fungal (Yeasts) } \\
\text { Strains }\end{array}$ & $\begin{array}{c}\mathrm{MIC} \\
{\left[\mathrm{mg} \mathrm{mL}^{-1}\right]}\end{array}$ & $\begin{array}{c}\mathrm{MFC} \\
{\left[\mathrm{mg} \mathrm{mL}^{-1}\right]}\end{array}$ & $\begin{array}{l}\text { MFCl } \\
\text { MIC }\end{array}$ & $\begin{array}{c}\mathrm{MIC} \\
{\left[\mathrm{mg} \mathrm{mL}^{-1}\right]}\end{array}$ & $\begin{array}{c}\mathrm{MFC} \\
{\left[\mathrm{mg} \mathrm{mL}^{-1}\right]}\end{array}$ & $\begin{array}{l}\mathrm{MFCl} \\
\mathrm{MIC}\end{array}$ \\
\hline $\begin{array}{l}\text { Candida albicans } \\
\text { ATCC } 10231\end{array}$ & 5 & 10 & 2 & 5 & 10 & 2 \\
\hline $\begin{array}{c}\text { Candida glabrata } \\
\text { ATCC } 90030\end{array}$ & 10 & 10 & 1 & 10 & 20 & 2 \\
\hline
\end{tabular}


Time-kill assays were performed exposing S. aureus ATCC 29213 to various concentrations of the $\mathrm{CO}_{2}+\mathrm{H}_{2} \mathrm{O}$ extracts obtained from $H$. salicifolius and $H$. tuberosus in order to confirm their bactericidal activity. S. aureus ATCC 29213 was chosen for this experiment due to its higher sensitivity to both extracts in comparison to E. coli ATCC 25922 and the yeast species. Moreover, it is a common human pathogen that causes a wide range of clinical infections. It is assumed that bactericidal effect is defined as greater than $3 \log _{10^{-}}$ fold decrease in CFU mL ${ }^{-1}$ in the presence of antimicrobials as compared to the initial inoculum [22]. As presented in Figure 2, bacterial killing by both extracts was found to be a concentration-dependent process; some biocidal effect occurred even at sub-inhibitory concentrations of both extracts, that was $0.1 \mathrm{mg} \mathrm{mL}^{-1}$ for $\mathrm{H}$. salicifolius extract and $1 \mathrm{mg}$ $\mathrm{mL}^{-1}$ for $H$. tuberosus extract. Moreover, $H$. salicifolius extract was more active than that of H. tuberosus.

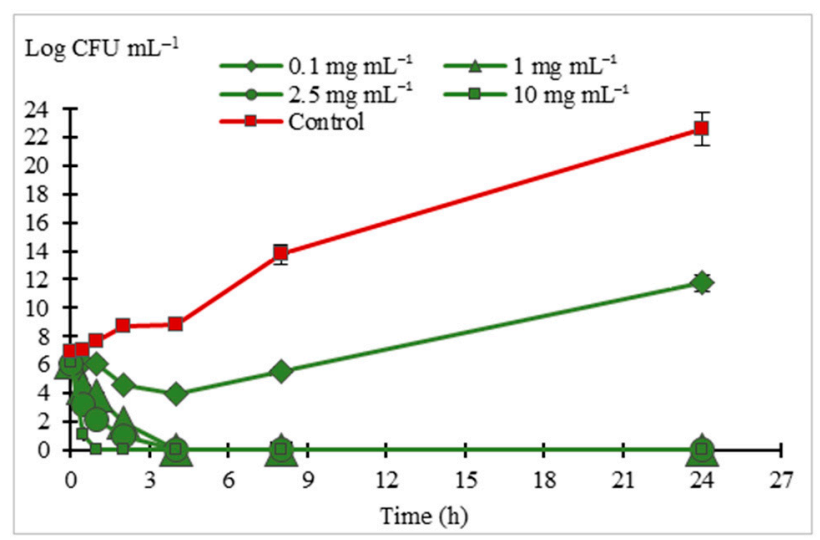

(a)

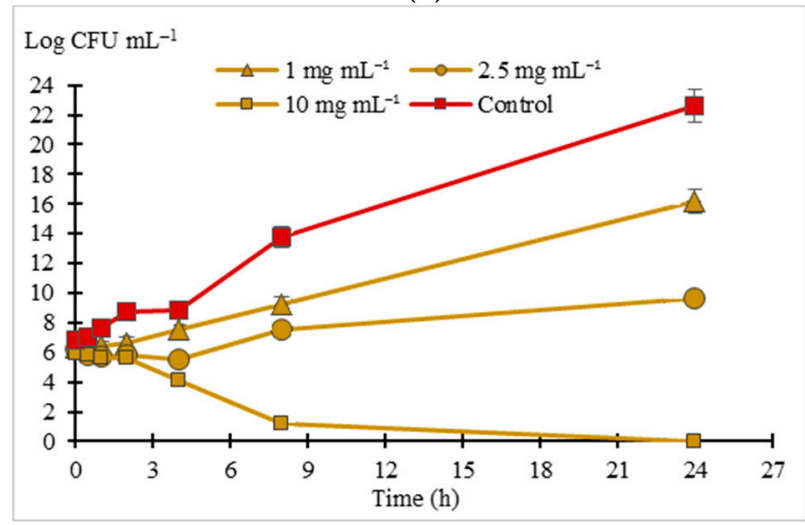

(c)

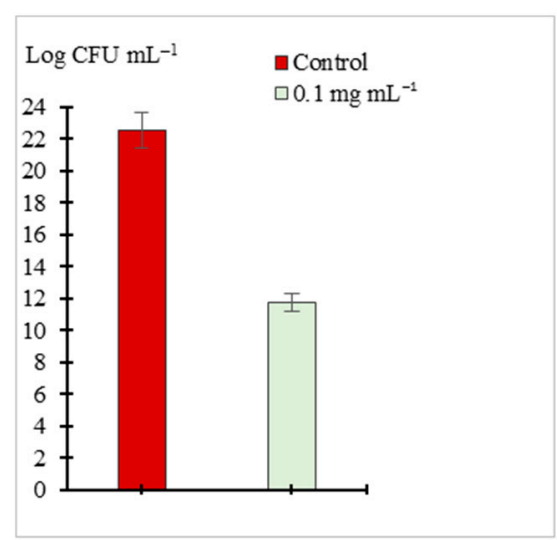

(b)

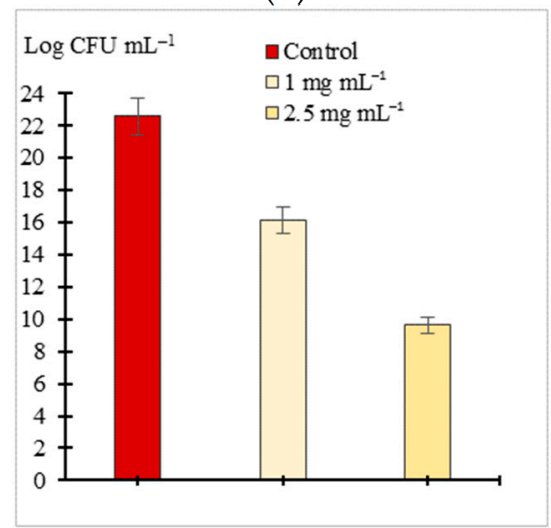

(d)

Figure 2. Time-kill curves for S. aureus ATCC 29213 at various concentrations of supercritical extracts obtained from: (a) H. salicifolius and (c) H. tuberosus with water as a co-solvent $\left(\mathrm{CO}_{2}+\mathrm{H}_{2} \mathrm{O}\right.$ extracts). Bacterial population density after $24 \mathrm{~h}$ exposure to various concentrations of the $\mathrm{CO}_{2}+\mathrm{H}_{2} \mathrm{O}$ extracts obtained from: (b) H. salicifolius and (d) H. tuberosus. Mean values \pm standard deviations are presented.

As presented in Figure 3, the $\mathrm{CO}_{2}+\mathrm{H}_{2} \mathrm{O}$ extracts obtained from $\mathrm{H}$. salicifolius and $\mathrm{H}$. tuberosus differed in the total polyphenol content (TPC) expressed as gallic acid equivalents (GAE). This was $13.75 \pm 0.50 \mathrm{mg} \mathrm{GAE}^{-1}$ of $\mathrm{H}$. salicifolius extract and $33.06 \pm 0.80 \mathrm{mg}$ GAE $\mathrm{g}^{-1}$ of $H$. tuberosus extract. Both extracts showed different antioxidant activity. $H$. tuberosus extract exhibited almost two-fold higher activity $\left(\mathrm{EC}_{50}=0.332 \pm 0.05 \mathrm{mg} \mathrm{mL}^{-1}\right)$ as compared to that of $H$. salicifolius $\left(\mathrm{EC}_{50}=0.609 \pm 0.29 \mathrm{mg} \mathrm{mL}^{-1}\right.$ ). However, a relationship was observed between the antioxidant potential of both extracts and TPC. It should be noted that despite two-fold lower TPC in the H. salicifolius extract than that in the H. tuberosus extract (Figure 3), activity of H. salicifolius extract against S. aureus ATCC 29213 was fourfold higher compared to $H$. tuberosus extract with MIC of $0.62 \mathrm{mg} \mathrm{mL}^{-1}$ or $2.5 \mathrm{mg} \mathrm{mL}^{-1}$ 
(Table 3), respectively. In contrast, activity of both extracts against E. coli ATCC 25922 and Candida spp. strains was comparable (Table 3), irrespective of TPC (Figure 3).

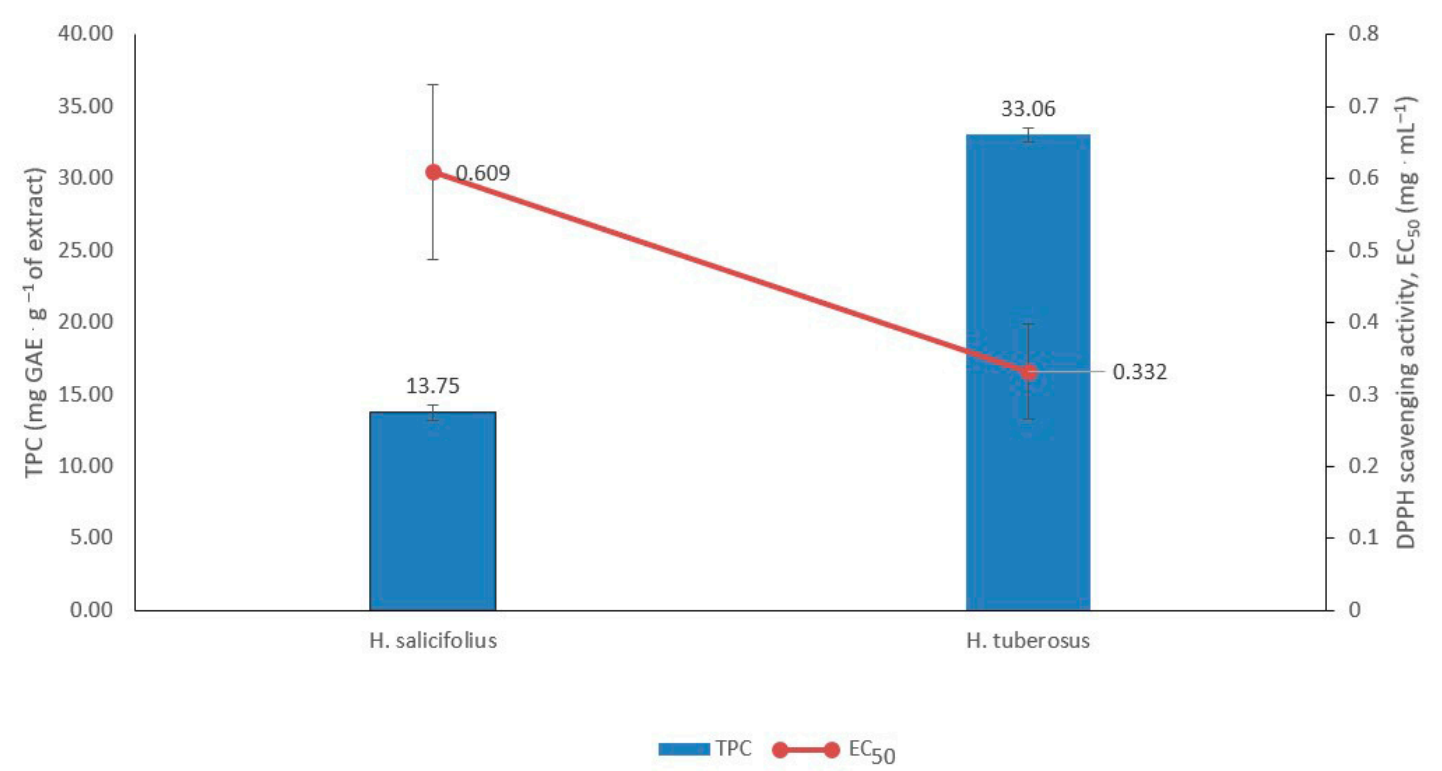

Figure 3. The total polyphenol content (TPC) in supercritical extracts obtained from $H$. salicifolius and H. tuberosus with water as a co-solvent $\left(\mathrm{CO}_{2}+\mathrm{H}_{2} \mathrm{O}\right.$ extracts) together with their antioxidant activity. Mean values \pm standard deviation were presented.

The ATR-FTIR spectra of $\mathrm{CO}_{2}+\mathrm{H}_{2} \mathrm{O}$ extracts from $\mathrm{H}$. salicifolius and $\mathrm{H}$. tuberosus are shown in Figure 4. Interpretation of these spectra was performed according to other authors [23-25]. The main vibrations of the characteristic groups were similar in both extracts; only slight diferrences were observed. At a wave-number of $3392 \mathrm{~cm}^{-1}$ for $H$. salicifolius extract and $3401 \mathrm{~cm}^{-1}$ for $H$. tuberosus extract, characteristic stretching vibrations were indicated that may have been induced from the $\mathrm{OH}$ group derived from carbohydrates proteins and polyphenols. In both analyzed spectra, cis $\mathrm{C}=\mathrm{C}$ stretching was observed for both extracts at a wavenumbers of 3009 and $3008 \mathrm{~cm}^{-1}$. The absorption bands around 2918 and $2849 \mathrm{~cm}^{-1}$ in the H. salicifolius extract spectrum and 2921 and $2851 \mathrm{~cm}^{-1}$ in the H. tuberosus extract spectrum may be due to asymmetric and symmetrical $\mathrm{CH}_{2}$ stretching vibrations, respectively, while the band at a wavenumber of $1742 \mathrm{~cm}^{-1}$ is characteristic of the $\mathrm{C}=\mathrm{O}$ stretching vibrations of aldehydes, ketones, and carboxylic acids. In the $H$. salicifolius extract, vibrations were recorded at a wavenumber of $1695 \mathrm{~cm}^{-1}$; this band is characteristic of the vibrations of amide I $\left(1600-1700 \mathrm{~cm}^{-1}\right)$, and the effect is related to the stretching vibrations of the $\mathrm{C}=\mathrm{O}$ and $\mathrm{C}-\mathrm{N}$ groups. Unconjugated stretching cis $\mathrm{C}=\mathrm{C}$ at $1657 \mathrm{~cm}^{-1}$ was also observed. The band at $1462 \mathrm{~cm}^{-1}$ wavenumber was probably generated by a $\mathrm{CH}_{2}$ scissor vibration. In contrast, the presence of the band at wavenumbers of $1369 \mathrm{~cm}^{-1}$ (H. salicifolius extract) and $1377 \mathrm{~cm}^{-1}$ (H. tuberosus extract) is characteristic of $\mathrm{CH}_{3}$ symmetrical bending vibration. At wavenumbers $1239,1167,1096$, and $1023 \mathrm{~cm}^{-1}$ and $1239,1162,1096$, and $1030 \mathrm{~cm}^{-1}$, respectively, for H. salicifolius and H. tuberosus extracts, stretching vibrations characteristic for the $\mathrm{C}-\mathrm{O}$ groups were also seen. Furthermore, in the range of $970-969 \mathrm{~cm}^{-1}$ wavenumbers, characteristic vibrations for the groups trans double bonds $(\mathrm{C}=\mathrm{C})$ and cis double bonds $(\mathrm{C}=\mathrm{C})$ were revealed. In addition, the bands at $720 \mathrm{~cm}^{-1}$ are typical of the $\mathrm{CH}_{2}$ groups. Moreover, at the wavenumber of $1323 \mathrm{~cm}^{-1}$ in the $\mathrm{H}$. salicifolius extract, there was an absorption of the band that could be derived from amide III (C-N stretch) with a significant share of $\mathrm{CH}_{2}$ carbohydrate residue. Table 4 shows major band assignments for the ATR-FTIR spectra of both $\mathrm{CO}_{2}+\mathrm{H}_{2} \mathrm{O}$ extracts. 


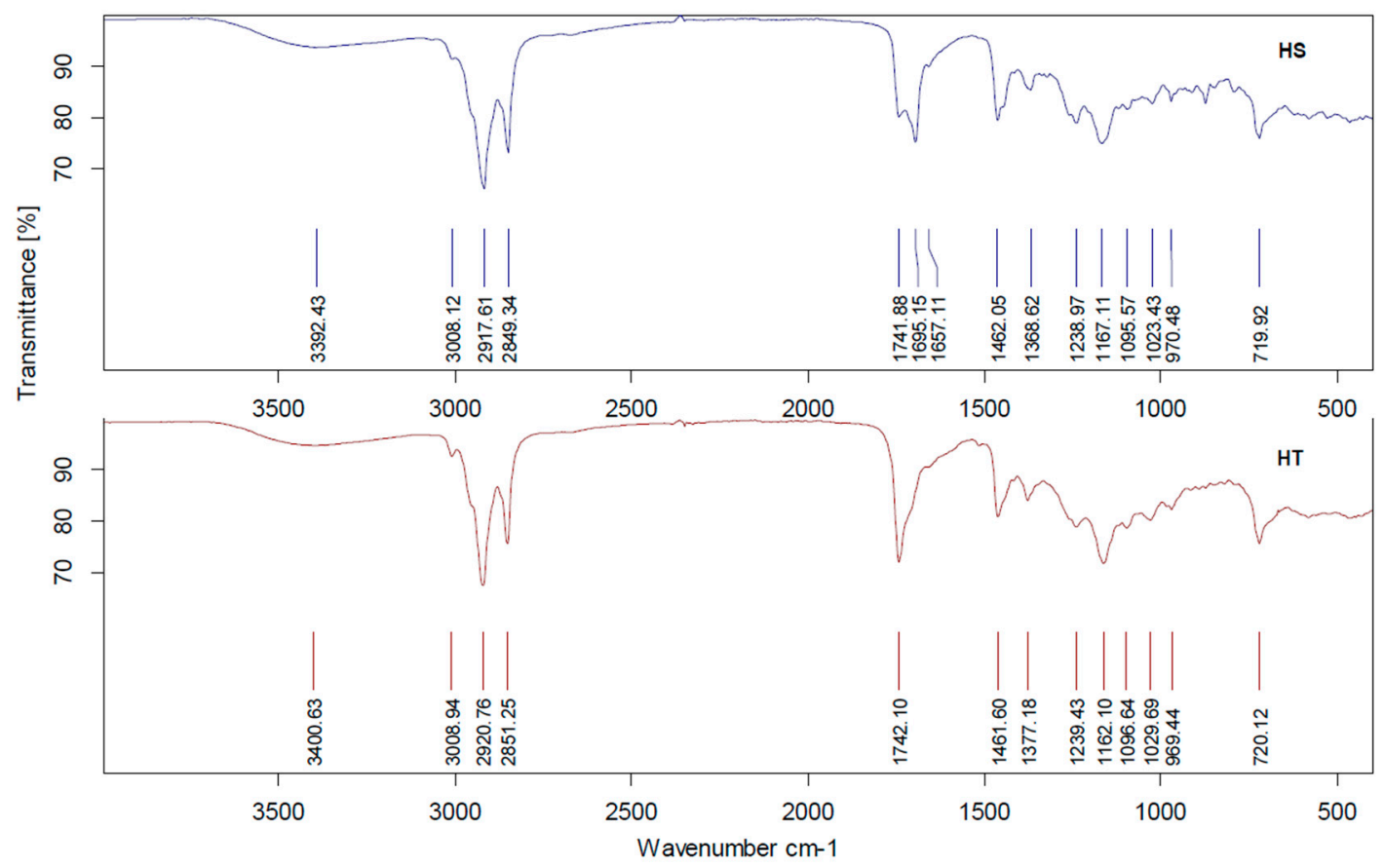

Figure 4. ATR-FTIR spectra of supercritical extracts obtained from H. salicifolius (HS) and H. tuberosus (HT) with water as a co-solvent $\left(\mathrm{CO}_{2}+\mathrm{H}_{2} \mathrm{O}\right.$ extracts).

Table 4. Major band assignments for the ATR-FTIR spectra of supercritical extracts obtained from $H$. salicifolius and $\mathrm{H}$. tuberosus with water as a co-solvent $\left(\mathrm{CO}_{2}+\mathrm{H}_{2} \mathrm{O}\right.$ extracts).

\begin{tabular}{|c|c|c|}
\hline \multicolumn{2}{|c|}{ Wavenumbers $\left(\mathrm{cm}^{-1}\right)$} & \multirow{2}{*}{ Functional Group Vibration } \\
\hline H. salicifolius & H. tuberosus & \\
\hline 3392 & 3401 & $\begin{array}{l}\text { OH stretching (carbohydrates, } \\
\text { proteins and polyphenols) }\end{array}$ \\
\hline 3008 & 3009 & cis $\mathrm{C}=\mathrm{C}$ stretching \\
\hline 2918,2849 & 2921,2851 & $\begin{array}{c}\text { asymmetric and symmetric stretching } \\
\text { vibration of } \mathrm{CH}_{2} \text { group }\end{array}$ \\
\hline 1742 & 1742 & $\begin{array}{c}\mathrm{C}=\mathrm{O} \text { stretching (aldehydes, ketones, } \\
\text { and carboxylic acids) }\end{array}$ \\
\hline 1695 & - & $\mathrm{C}=\mathrm{O}$ and $\mathrm{C}-\mathrm{N}$ stretching vibrations \\
\hline 1657 & - & unconjugated cis $\mathrm{C}=\mathrm{C}$ \\
\hline 1462 & 1462 & $\mathrm{CH}_{2}$ scissor vibration \\
\hline 1369 & 1377 & $\mathrm{CH}_{3}$ symmetrical bending vibration \\
\hline $1239,1167,1096,1023$ & $1239,1162,1096,1030$ & C-O stretching vibration \\
\hline 970 & 969 & $\begin{array}{c}\text { trans double bonds }(\mathrm{C}=\mathrm{C}) \text { and cis } \\
\text { double bonds }(\mathrm{C}=\mathrm{C})\end{array}$ \\
\hline 720 & 720 & $\begin{array}{c}\text { bending (rocking) of }-\left(\mathrm{CH}_{2}\right)_{n^{-}},-\mathrm{HC}- \\
\mathrm{CH}-(\mathrm{cis})\end{array}$ \\
\hline
\end{tabular}

\section{Discussion}

Data presented in this paper showed that $\mathrm{CO}_{2}+\mathrm{H}_{2} \mathrm{O}$ extracts obtained from both $\mathrm{He}$ lianthus species possessed antimicrobial potential, including activity against Gram-positive bacteria (S. aureus) and Gram-negative bacteria (E. coli), as well as yeasts (C. albicans and C. glabrata). Both extracts exerted bactericidal and fungicidal effect. It should be noted that the above microbial species, present within human skin, oral, and gut microbiota, may be regarded as commensals or pathogens, depending on the host-microbe interactions [13-15]. Moreover, these microorganisms may be a cause of cosmetics or food contamination, hence the need to protect these products by substances with antimicrobial activity-conservants or preservatives, respectively $[26,27]$. According to the literature data [9-11], extracts from 
$H$. tuberosus leaves might be a promising source of natural fungicides active against several phytopathogens, among them caffeoylquinic acid derivatives. However, Liu et al. [9] found that the inhibitory effects of aqueous extracts were significantly less than those of extracts of organic solvents, i.e., petroleum ether, ethyl ether, and ethyl acetate. Of note, there is no literature data on bioactivity and chemical composition of the supercritical extracts obtained from the aerial parts of $H$. tuberosus and $H$. salicifolius using water as co-solvent $\left(\mathrm{CO}_{2}+\mathrm{H}_{2} \mathrm{O}\right.$ extracts). This is the first report.

The antistaphylococcal activity of $\mathrm{CO}_{2}+\mathrm{H}_{2} \mathrm{O}$ extracts obtained from $H$. salicifolius and from $H$. tuberosus should be underlined. $S$. aureus is known to be an important pathogen related to skin and soft tissue, as well as to food-borne infections [28]. In this paper, we found higher antistaphylococcal effect of $\mathrm{H}$. salicifolius $\mathrm{CO}_{2}+\mathrm{H}_{2} \mathrm{O}$ extract, as compared to that of $H$. tuberosus $\mathrm{CO}_{2}+\mathrm{H}_{2} \mathrm{O}$ extract. In contrast, it was found that TPC was higher in $H$. tuberosus extract, in comparison to that in H. salicifolius extract. Yuan et al. [29] showed that TPC in aqua ethanolic extracts from $H$. tuberosus leaves was $101.07 \mathrm{mg} \mathrm{GAE}^{-1}$ of dry extract. More detailed studies by Showkat et al. [30] revealed that TPC in H. tuberosus was dependent on the plant organ. They determined higher TPC, expressed as $\mathrm{mg} \mathrm{GAE} \mathrm{g}^{-1}$ of dry substance, in ethanolic extracts from leaves (7.9-11.1) than in flower (4.0-5.3), tuber (2.8-3.8), and stem (0.9-1.7) extracts. However, these authors found the overestimation of $\mathrm{TPC}$ in the extracts from various organs ranging from $65 \%$ (in flowers) to $94 \%$ (in stems) and used the Folin-Ciocalteu assay, applying the correction for ascorbic acid.

It should be noted that polyphenols have been recognized as one of the largest and most widespread group of plant secondary metabolites, responsible for both antimicrobial and antioxidant activity [31]. Data presented in this paper suggest that the antistaphylococcal activity of both $\mathrm{CO}_{2}+\mathrm{H}_{2} \mathrm{O}$ extracts, especially that from $\mathrm{H}$. salicifolius, may be due to the content of other plant secondary metabolites such as sesquiterpene lactones [32]. These compounds can be regarded as one of the most prevalent and biologically significant classes of plant secondary metabolites, including that in plants from Asteraceae family, e.g. H. tuberosus [29]. Sesquiterpene lactones have been assumed to be potent antimicrobials. Some are also considered to be antioxidants [33,34].

The antimicrobial properties of plant-derived products are generally accompanied by a confirmed antioxidant capacity $[29,31-34]$. In this paper, we found higher antioxidant effect of $H$. tuberosus $\mathrm{CO}_{2}+\mathrm{H}_{2} \mathrm{O}$ extract together with its higher TPC, as compared to those of $H$. salicifolius $\mathrm{CO}_{2}+\mathrm{H}_{2} \mathrm{O}$ extract. These data suggest that the antioxidant properties of $\mathrm{CO}_{2}+$ $\mathrm{H}_{2} \mathrm{O}$ extracts studied may be related to polyphenols content, which is in agreement with the literature data $[35,36]$. The DPPH assay included in this study for the determination of antioxidant activities of the $\mathrm{CO}_{2}+\mathrm{H}_{2} \mathrm{O}$ extracts from both Helianthus species was also used by other authors $[30,37,38]$ in studying the radical scavenging activity of $H$. tuberosus. Showkat et al. [30], for example, showed significant correlation between TPC and radical scavenging activity of ethanolic extracts from $H$. tuberosus leaves. These authors revealed, similarly to Yuan et al. [37] and Nizioł et al. [38], that aqua-ethanolic or ethanolic extracts from $H$. tuberosus leaves, in comparison to those from other organs of this plant (e.g. tubers), possessed higher radical scavenging activity (with $\mathrm{EC}_{50}$ about $0.075-0.25 \mathrm{mg} \mathrm{mL}^{-1}$ ) and could be a potential source of natural antioxidants.

The ATR-FTIR spectroscopic imaging is a suitable technique, not only as a method of identity confirmation, but also for detecting and identifying molecular components in a complex plant matrix [23]. Preliminary phytochemical analysis of both $\mathrm{CO}_{2}+\mathrm{H}_{2} \mathrm{O}$ extracts by ATR-FTIR indicated the presence of similar main vibrations of the functional groups typical for phytoconsituents possessing bioactivity such as polyphenols, aldehydes, ketones, or carboxylic acids [23-25].

\section{Conclusions}

The presented data suggest that supercritical extracts with water as a co-solvent obtained from the aerial parts of $H$. salicifolius and $H$. tuberosus collected in summer period appeared to be a promising source of natural compounds with biocidal effect. They 
possessed antibacterial activity against Gram-positive (S. aureus) and Gram-negative (E. coli) species (MIC $=0.62-5 \mathrm{mg} \mathrm{mL}^{-1}$ ), as well as antifungal activity against yeasts from Candida genus (MIC $=5-10 \mathrm{mg} \mathrm{mL}^{-1}$ ). It is worth notifying their antistaphylococcal activity (MIC $=0.62-2.5 \mathrm{mg} \mathrm{mL}^{-1}$ ). These extracts may be also regarded as natural potential antioxidants $\left(\mathrm{EC}_{50}=0.332-0.609 \mathrm{mg} \mathrm{mL}^{-1}\right)$. The ATR-FTIR spectra of both extracts showed similar main vibrations of the functional groups typical for phytoconstituents possessing bioactivity. The obtained data, together with those from literature, suggest that these extracts and their isolated bioactive compounds may be used as conservants in cosmetics and/or natural preservatives in food. However, further studies are needed to confirm the obtained results, to define and to quantify constituents present in both extracts, as well as to identify specific applications of supercritical extracts and their phytoconstituents from biomass of these two plant species.

Author Contributions: Conceptualization: A.M., E.R., and M.J.S.; data curation, A.M., E.R., and M.J.S.; formal analysis, A.M., E.R., and M.J.S.; funding acquisition: M.J.S., A.M., and E.R.; investigation: A.M., E.R., M.J.S., A.G., A.B., T.B., K.T., and A.D.; methodology: A.M., E.R., M.J.S., A.G., A.B., T.B., K.T., A.D., M.K., and E.O.-Z.; project administration: A.M. and M.J.S.; validation: A.M., E.R., and M.J.S.; visualization: A.M., E.R., and M.J.S.; writing—original draft: A.M., E.R., and M.J.S.; writing-review and editing: A.M., E.R., M.J.S., A.G., A.B., T.B., K.T., A.D., M.K., and E.O.-Z. All authors have read and agreed to the published version of the manuscript.

Funding: This research was funded by the National (Polish) Centre for Research and Development $(\mathrm{NCBiR})$, entitled "Environment, agriculture and forestry", project: BIOproducts from lignocellulosic biomass derived from Marginal land to fill the Gap In Current national bioeconomy, No. BIOSTRATEG3/344253/2/NCBR/2017.

Institutional Review Board Statement: This study did not require ethical approval.

Informed Consent Statement: Not applicable.

Data Availability Statement: Not applicable.

Acknowledgments: We would also like to thank the staff of the Department of Plant Breeding and Seed Production, Didactic and Research Station in Bałdy and Quercus Sp. z o.o. for their technical support during the experiment.

Conflicts of Interest: The authors declare no conflict of interest.

\section{References}

1. Rossini, F.; Provenzano, M.E.; Kuzmanović, L.; Ruggeri, R. Jerusalem artichoke (Helianthus tuberosus L.): A versatile and sustainable crop for renewable energy production in Europe. Agronomy 2019, 9, 528. [CrossRef]

2. Stolarski, M.J.; Śnieg, M.; Krzyżaniak, M.; Tworkowski, J.; Szczukowski, S. Short rotation coppices, grasses and other herbaceous crops: Productivity and yield energy value versus 26 genotypes. Biomass Bioenergy 2018, 119, 109-120. [CrossRef]

3. Volk, G.M.; Richards, K. Preservation methods for Jerusalem artichoke cultivars. HortScience 2006, 41, 80-83. [CrossRef]

4. Matias, J.; Gonzalez, J.; Cabanillas, J.; Royano, L. Influence of NPK fertilization and harvest date on agronomic performance of Jerusalem artichoke crop in the Guadiana Basin (Southwestern Spain). Ind. Crop. Prod. 2013, 48, 191-197. [CrossRef]

5. Yang, L.; He, Q.S.; Corscadden, K.; Udenigwe, C.C. The prospects of Jerusalem artichoke in functional food ingredients and bioenergy production. Biotechnol. Rep. 2015, 5, 77-88. [CrossRef]

6. Stolarski, M.J.; Śnieg, M.; Krzyżaniak, M.; Tworkowski, J.; Szczukowski, S.; Graban, Ł.; Lajszner, W. Short rotation coppices, grasses and other herbaceous crops: Biomass properties versus 26 genotypes and harvest time. Ind. Crop. Prod. 2018, 119, 22-32. [CrossRef]

7. Kokoska, L.; Kloucek, P.; Leuner, O.; Novy, P. Plant-derived products as antibacterial and antifungal agents in human health care. Curr. Med. Chem. 2019, 26, 5501-5541. [CrossRef]

8. Szewczyk, A.; Zagaja, M.; Bryda, J.; Kosikowska, U.; Stępień-Pyśniak, D.; Winiarczyk, S.; Andres-Mach, M. Topinambur - new possibilities for use in a supplementation diet. Ann. Agric. Environ. Med. 2019, 26, 24-28. [CrossRef]

9. Liu, H.W.; Liu, Z.P.; Liu, L.; Zhao, G.M. Studies on the antifungal activities and chemical components of extracts from Helianthus tuberosus leaves. Nat. Prod. Res. Dev. 2007, 19, 405-409.

10. Chen, F.; Long, X.; Yu, M.; Liu, Z.; Liu, L.; Shao, H. Phenolics and antifungal activities analysis in industrial crop Jerusalem artichoke (Helianthus tuberosus L.) leaves. Ind. Crop. Prod. 2013, 47, 339-345. [CrossRef]

11. Chen, F.J.; Long, X.H.; Li, E.Z. Evaluation of antifungal phenolics from Helianthus tuberosus L. leaves against Phytophthora capsici Leonian by chemometric analysis. Molecules 2019, 24, 4300. [CrossRef] [PubMed] 
12. Kaszás, L.; Alshaal, T.; Kovács, Z.; Koroknai, J.; Elhawat, N.; Nagy, E.; El-Ramady, H.; Fári, M.; Domokos-Szabolcsy, É. Refining high-quality leaf protein and valuable co-products from green biomass of Jerusalem artichoke (Helianthus tuberosus L.) for sustainable protein supply. Biomass Conv. Bioref. 2020. [CrossRef]

13. Cogen, A.L.; Nizet, V.; Gallo, R.L. Skin microbiota: A source of disease or defence? Br. J. Dermatol. 2008, 158, 442-455. [CrossRef] [PubMed]

14. Pickard, J.M.; Zeng, M.Y.; Caruso, R.; Núñez, G. Gut microbiota: Role in pathogen colonization, immune responses, and inflammatory disease. Immunol. Rev. 2017, 279, 70-89. [CrossRef]

15. Arweiler, N.B.; Netuschil, L. The oral microbiota. Adv. Exp. Med. Biol. 2016, 902, 45-60. [CrossRef]

16. Clarke, G.; Ting, K.N.; Wiart, C.; Fry, J. High correlation of 2,2-diphenyl-1-picrylhydrazyl (DPPH) radical scavenging, ferric reducing activity potential and total phenolics content indicates redundancy in use of all three assays to screen for antioxidant activity of extracts of plants from the Malaysian rainforest. Antioxidants 2013, 2, 1-10. [CrossRef]

17. Nickavar, B.; Esbati, N. Evaluation of the antioxidant capacity and phenolic content of three Thymus species. J. Acupunct. Meridian Stud. 2012, 5, 119-125. [CrossRef]

18. Alara, O.R.; Abdurahman, N.H.; Mudalip, S.K.A.; Olalere, O.A. Characterization and effect of extraction solvents on the yield and total phenolic content from Vernonia amygdalina leaves. J. Food Meas. Charact. 2018, 12, 311-316. [CrossRef]

19. European Committee for Antimicrobial Susceptibility Testing (EUCAST) of the European Society of Clinical Microbiology and Infectious Diseases (ESCMID): Determination of minimum inhibitory concentrations (MICs) of antibacterial agents by broth dilution. EUCAST Discussion Document E.Dis 5.1; The European Committee on Antimicrobial Susceptibility Testing. Clin. Microbiol. Inf. Dis. 2003, 9, 1-7.

20. Gai, F.; Karamać, M.; Janiak, M.A.; Amarowicz, R.; Peiretti, P.G. Sunflower (Helianthus annuus L.) plants at various growth stages subjected to extraction-comparison of the antioxidant activity and phenolic profile. Antioxidants 2020, 9, 535. [CrossRef]

21. Pankey, G.A.; Sabath, L.D. Clinical relevance of bacteriostatic versus bactericidal mechanisms of action in the treatment of gram-positive bacterial infections. Clin. Infect. Dis. 2004, 38, 864-870. [CrossRef]

22. Silva, F.; Lourenço, O.; Queiroz, J.A.; Domingues, F.C. Bacteriostatic versus bactericidal activity of ciprofloxacin in Escherichia coli assessed by flow cytometry using a novel far-red dye. J. Antibiot. (Tokyo) 2011, 64, 321-325. [CrossRef] [PubMed]

23. Huck, C.W. Advances of infrared spectroscopy in natural product research. Phytochem. Lett. 2015, 11, 384-393. [CrossRef]

24. Jiménez-Sotelo, P.; Hernández-Martínez, M.; Osorio-Revilla, G.; Meza-Márquez, O.G.; García-Ochoa, F.; Gallardo-Velázquez, T. Use of ATR-FTIR spectroscopy coupled with chemometrics for the authentication of avocado oil in ternary mixtures with sunflower and soybean oils. Food Addit. Contam Part A 2016, 33, 1105-1115. [CrossRef] [PubMed]

25. Rai, A.; Mohanty, B.; Bhargava, R. Supercritical extraction of sunflower oil: A central composite design for extraction variables. Food Chem. 2016, 192, 647-659. [CrossRef]

26. Halla, N.; Fernandes, I.P.; Heleno, S.A.; Costa, P.; Boucherit-Otmani, Z.; Boucherit, K.; Rodrigues, A.E.; Ferreira, I.C.F.R.; Barreiro, M.F. Cosmetics preservation: A review on present strategies. Molecules 2018, 23, 1571. [CrossRef]

27. Pisoschi, A.M.; Pop, A.; Georgescu, C.; Turcuş, V.; Olah, N.K.; Mathe, E. An overview of natural antimicrobials role in food. Eur. J. Med. Chem. 2018, 143, 922-935. [CrossRef]

28. Tong, S.Y.C.; Davis, J.S.; Eichenberger, E.; Holland, T.L.; Fowler, V.G., Jr. Staphylococcus aureus infections: Epidemiology, pathophysiology, clinical manifestations, and management. Clin. Microbiol. Rev. 2015, 28, 603-661. [CrossRef]

29. Yuan, X.; Yang, Q. Simultaneous quantitative determination of 11 sesquiterpene lactones in Jerusalem artichoke (Helianthus tuberosus L.) leaves by ultrahigh performance liquid chromatography with quadrupole time-of-flight mass spectrometry. J. Sep. Sci. 2017, 40, 1457-1464. [CrossRef]

30. Showkat, M.M.; Falck-Ytter, A.B.; Strætkvern, K.O. Phenolic acids in Jerusalem artichoke (Helianthus tuberosus L.): Plant organ dependent antioxidant activity and optimized extraction from leaves. Molecules 2019, 24, 3296. [CrossRef]

31. Mojzer, E.B.; Hrnčič, M.K.; Škerget, M.; Knez, Ž.; Bren, U. Polyphenols: Extraction methods, antioxidative action, bioavailability and anticarcinogenic effects. Molecules 2016, 21, 901. [CrossRef]

32. Cartagena, E.; Alva, M.; Montanaro, S.; Bardón, A. Natural sesquiterpene lactones enhance oxacillin and gentamicin effectiveness against pathogenic bacteria without antibacterial effects on beneficial lactobacilli. Phytother. Res. 2015, 29, 695-700. [CrossRef] [PubMed]

33. Chadwick, M.; Trewin, H.; Gawthrop, F.; Wagstaff, C. Sesquiterpenoids lactones: Benefits to plants and people. Int. J. Mol. Sci. 2013, 14, 12780-12805. [CrossRef] [PubMed]

34. Fraga, B.M. Natural sesquiterpenoids. Nat. Prod. Rep. 2001, 18, 650-673. [PubMed]

35. Xu, D.P.; Li, Y.; Meng, X.; Zhou, T.; Zhou, Y.; Zheng, J.; Zhang, J.J.; Li, H.B. Natural antioxidants in foods and medicinal plants: Extraction, assessment and resources. Int. J. Mol. Sci. 2017, 18, 96. [CrossRef] [PubMed]

36. Dontha, S. A review on antioxidant methods. Asian J. Pharm. Clin. Res. 2016, 9, 14-32. [CrossRef]

37. Yuan, X.; Gao, M.; Xiao, H.; Tan, C.; Du, Y. Free radical scavenging activities and bioactive substances of Jerusalem artichoke (Helianthus tuberosus L.) leaves. Food Chem. 2012, 133, 10-14. [CrossRef]

38. Nizioł-Łukaszewska, Z.; Furman-Toczek, D.; Zagórska-Dziok, M. Antioxidant activity and cytotoxicity of Jerusalem artichoke tubers and leaves extract on HaCaT and BJ fibroblast cells. Lipids Health Dis. 2018, 17, 280-292. [CrossRef] 